\title{
DNA sequences of human papillomavirus types 11, 16, and 18 in lesions of the uterine cervix in the west of Scotland
}

\author{
D W M MILLAN, J A DAVIS, T E TORBET, M S CAMPO
}

\begin{abstract}
Punch biopsy specimens of the cervix were examined both histologically and for the presence of human papillomavirus (HPV) DNA sequences. The presence of HPV DNA sequences was sought with the Southern blot technique using radioactively labelled HPV-6, 11, 16, and 18 DNA probes, both together and separately. Twenty six biopsy specimens were examined. Histological examination showed cervical intraepithelial neoplasia grade 2 or 3 in 16 specimens, viral changes (koilocytosis) in four, and inflammation or a normal appearance in three. Eleven specimens were negative for HPV DNA sequences, 10 contained HPV-16 DNA, four contained HPV-18 DNA, and one contained both HPV-18 and HPV-11 DNA. Episomal HPV-16 DNA was detected in one case of cervical intraepithelial neoplasia grade 3 and in five cases of cervical intraepithelial neoplasia grade $2 / 3$ with koilocytosis; and episomal HPV-18 DNA was found in two specimens classed as cervical intraepithelial neoplasia grade $2 / 3$, one of which also contained HPV-11 DNA, and in one specimen that showed viral changes alone. Integrated HPV DNA was found in six specimens (four with HPV-16 DNA and two with HPV-18 DNA), including two cases of chronically inflamed cervix with no histological evidence of viral infection or cervical intraepithelial neoplasia.

Detection of viral DNA in early lesions may identify patients at risk of malignant progression. This is the first report of HPV-18 DNA in cervical intraepithelial neoplasia in Scotland.
\end{abstract}

Stobhill General Hospital and Western Infirmary, Glasgow

DW M MILLAN, BSC, MB, registrar, departments of pathology

Stobhill General Hospital, Glasgow

J A DAVIS, MRCOG, consultant, department of obstetrics and gynaecology

Southern General Hospital, Glasgow

T E TORBET, FRCSED, FRCOG, consultant, division of obstetrics and gynaecology

Beatson Institute for Cancer Research, Glasgow G61 1BD

M S CAMPO, BSC, PHD, senior scientist

Correspendence to: Dr Campo.

\section{Introduction}

Carcinoma of the cervix, as judged from epidemiological evidence, seems to be a venereal disease. Sexual intercourse at an early age, multiple sexual partners, previous treatment for venereal disease, and a partner suffering from penile condyloma acuminatum are all associated with an increased risk of developing cervical carcinoma. ${ }^{22}$ From this evidence it has been suggested that a transmissible agent has a role in the aetiology of this cancer. Human papillomavirus (HPV) in association with synergistic factors is considered to be a likely candidate. ${ }^{3}$

Papillomaviruses cause a wide variety of neoplastic lesions in many animals and in $\operatorname{man}^{4}$ which in some cases show a natural progression to malignant cancers. In man at least 33 different types of HPV have been identified and the association of particular virus types with specific lesions has been recognised.

Several HPV types have been detected both in carcinoma of the uterine cervix and in its associated premalignant condition, cervical intraepithelial neoplasia. In particular, HPV-6, 11, and 16 have all been found in cervical intraepithelial neoplasia and HPV-16 and 18 DNA sequences have been found in several cases of carcinoma of the cervix, ${ }^{5-7}$ prompting the suggestion that infection by certain HPV types represents an increased risk factor and may be diagnostic of malignant conversion.

We report the presence of HPV-11,16, and 18 DNA sequences in punch biopsy specimens of the cervix.

\section{Patients and methods}

Cervical punch biopsy specimens were collected at routine colposcopy clinics at Stobhill and Southern General hospitals in Glasgow. Two specimens were taken from the same site; one was placed in $10 \%$ formol saline and processcd for routine histological examination and the other was snap frozen in liquid nitrogen and stored at $-70^{\circ} \mathrm{C}$ until further use. DNA was extracted and purified from the frozen material by the guanidinium thiocyanate procedure. ${ }^{8}$ It was digested with restriction endonucleases according to the manufacturer's instructions (BRL, United Kingdom, or Boehringer Mannheim), subjected to electrophoresis in $1 \%$ agarose gels, stained and photographed, ${ }^{9}$ and blotted on to Biodyne A nylon membranes. ${ }^{10} \mathrm{HPV}-6,11,16$, and 18 DNA was excised from recombinant plasmids by digestion with the appropriate restriction enzyme labelled with phosphorus- 32 by nick translation ${ }^{11}$ and incubated with membranes 
overnight in either $30 \%$ formamide and $5 \times$ SSC at $42^{\circ} \mathrm{C}$ (SSC $=0.15 \mathrm{M}$ sodium chloride and $0.015 \mathrm{M}$ sodium citrate, $\mathrm{pH} 7 \cdot 0$ ) or $40 \%$ formamide and $5 \mathrm{xSSC}$ at $42^{\circ} \mathrm{C}$. The membranes were then washed extensively in either 1xSSC at $42^{\circ} \mathrm{C}$ with a final wash in $0.5 \mathrm{xSSC}$ at $42^{\circ} \mathrm{C}$ or, for more stringent conditions, in $0.1 \mathrm{xSSC}$ at $60^{\circ} \mathrm{C}$ followed by exposure to $x$ ray films at $-70^{\circ} \mathrm{C}$ for different times.

\section{Results}

The histological appearance and HPV DNA content of 26 colposcopically directed punch biopsy specimens of the uterine cervix were examined. The histological appearances fell into five categories, comprising cervical intraepithelial neoplasia grade 2 or 3 as defined by Buckley et al ${ }^{12}$ with or without evidence of viral infection (koilocytosis) as defined by Dyson et $a l^{13}$ genomic DNA extra bands were seen (indicated with arrowheads in fig $2 c, e$ ), which probably represent the junctions between cellular and viral DNA. We cannot, however, rule out the presence of oligomeric viral genomes. Oligomeric forms of papillomavirus DNA have been reported in several systems, ${ }^{15}$ and it is possible that the high molecular weight bands in the untreated samples represented such forms and that the extra bands in the samples digested with PstI were due to intramolecular recombination.

Five specimens (19\%) contained viral DNA identified as HPV-18 by its strong hybridisation to the HPV-18 probe even in stringent conditions of hybridisation and washing. In three specimens the viral DNA was present as multiple monomeric episomes (fig $1 A, b-g$ and fig 3 ). One of these specimens showed histological evidence of viral infection only and no cervical intraepithelial neoplasia (table). In one case of cervical intraepithelial neoplasia grade 3 with histological evidence of viral infection two extra bands were seen in the DNA sample digested with PstI hybridised to the mixed probe (fig $1 A, g$ ), which were absent when the sample was hybridised to the

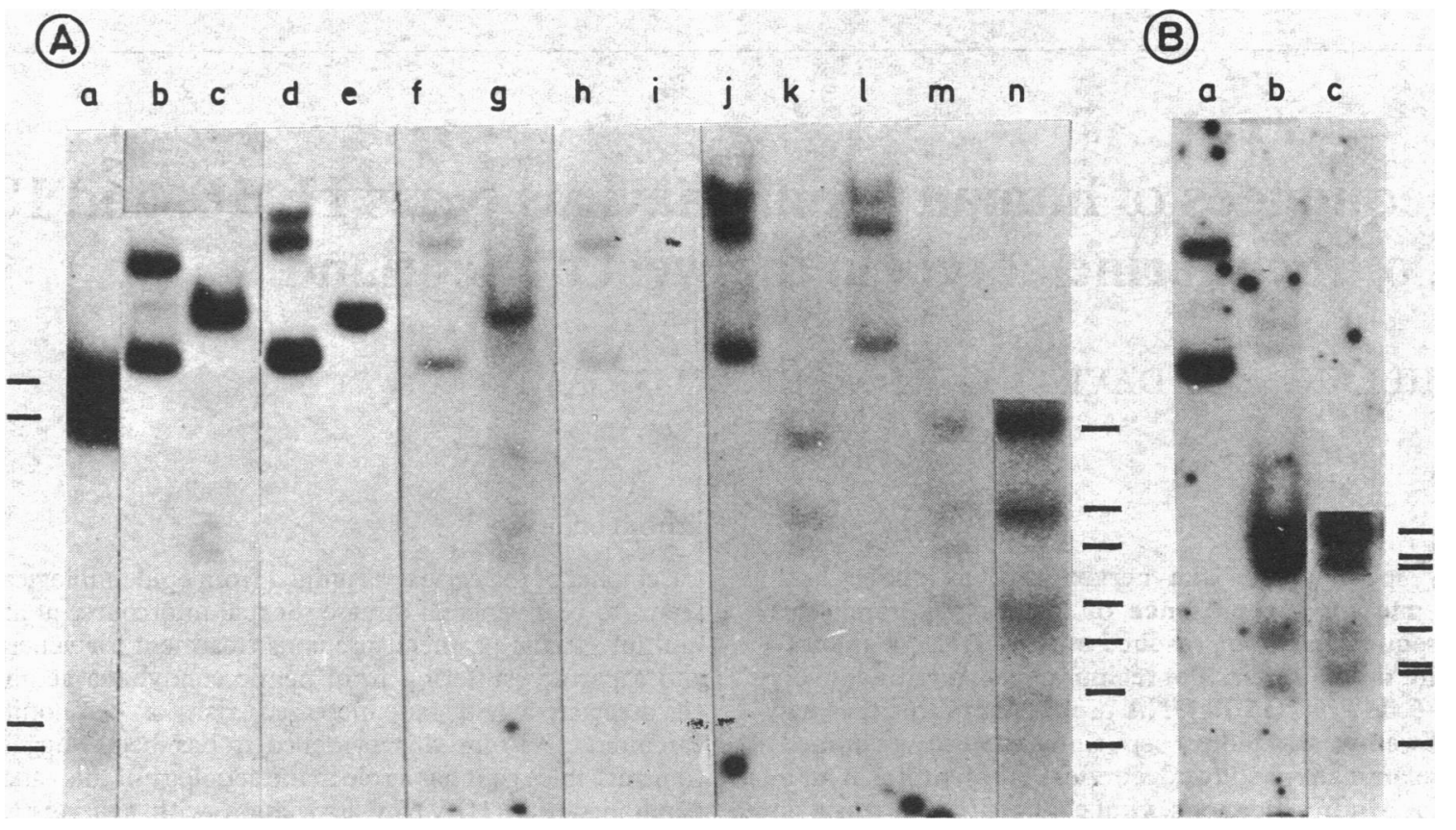

FIG 1-Detection of episomal HPV DNA sequences in cervical biopsy specimens. A: Tissue DNA hybridised to mixed HPV-6, 11, 16, and 18 probes labelled with phosphorus-32. $a$, EcoRI linear HPV-18 DNA digested with PstI; $b, c$, koilocytic atypia; $d, e$, cervical intraepithelial neoplasia (CIN) grade 2 with koilocytic atypia; $f, g$, CIN grade 3 with koilocytic atypia; $h, i$, CIN grade $3 ; j, k$, CIN grade 3 with koilocytic atypia; $l, m, C I N$ grade 2 with koilocytic atypia (in each case the first track contains non-digested DNA and the second track DNA digested with PstI); and $n$, Bam HI linear HPV-16 DNA digested with PstI. The amount of DNA was $10 \mu g$ in tracks $b, c$ and $f-i$ and $5 \mu g$ in tracks $d, e$ and $j-m$. Hybridisation was in $30 \%$ formamide $5 \times S S C$ at $42^{\circ} \mathrm{C}$. The sample in $b, c$ was run in a different gel, and therefore its electrophoretic mobility is not directly comparable with that of the remaining tracks. $B$ : The blot shown in $A$ was washed in $0 \cdot 1 \mathrm{xSSC}$ at $75^{\circ} \mathrm{C}$ to remove hybridised HPV probes and was rehybridised to HPV-11 DNA labelled with phosphorus- 32 in $40 \%$ formamide $5 \times$ SSC at $42^{\circ} \mathrm{C} . a, b$, same as $f, g$ in $A . c$, Bam HI linear HPV-11 DNA digested with PstI. Black lines indicate viral DNA fragments. The viral DNAs used as markers were excised from recombinant plasmids and were linear rather than circular, therefore producing an additional fragment after PstI digestion. Accordingly, PstI cut EcoRI linear HPV-18 DNA into four fragments of approximately 3.8, 2.8, 0.54, and 0.40 kb, whereas in the three cases containing circular episomal HPV-18 DNA PstI digestion produced one band of approximately $7 \mathrm{~kb}$ and two smaller bands, 0.54 and $0.46 \mathrm{~kb}$ (more visible in fig $3 A e$ ). The PstI restriction pattern of HPV-16 and HPV-11 DNA is as previously reported. ${ }^{\text {so }}$

viral infection alone, apparently normal or inflamed tissue, and squamous cell carcinoma of the cervix (table).

DNA from these specimens was hybridised to radioactively labelled HPV DNAs, and viral sequences were detected in $15(61 \%)$ cases (table), in agreement with previous studies. ${ }^{514} \mathrm{HPV}-16$ DNA sequences, identified on the basis of the PstI restriction enzyme fragment pattern ${ }^{6}$ (fig $1 A$ ), were detected in $10(38 \%)$ specimens, which contained all five histological categories. In six specimens the viral DNA was present as multiple episomal monomers, as exemplified by three cases shown in figure $1 A(h-m)$. In addition, two of these specimens from cervical intraepithelial neoplasia stage 3 with koilocytosis (fig $1 A, j$ ) and cervical intraepithelial neoplasia grade 2 with koilocytosis (fig $1 A, l$ ), were positive for the papillomavirus common antigen ( $R$ Hawthorn, personal communication), thus indicating that the lesions were producing viral progeny. In the remaining four specimens the viral DNA appeared to be integrated into the host cell genome, as exemplified in the two cases shown in fig 2 . In the untreated samples the viral DNA comigrated with the bulk of the cellular DNA (fig $2 b, d$ ); in the samples digested with PstI, in addition to the bands corresponding to viral
Histological findings and presence of HPV DNA in cervical biopsy specimens

\begin{tabular}{llllll}
\hline \multirow{2}{*}{$\begin{array}{l}\text { No of } \\
\text { cases }\end{array}$} & $\begin{array}{c}\text { No HPV DNA } \\
\text { negative }\end{array}$ & \multicolumn{3}{c}{ No positive for: } \\
\cline { 5 - 6 } & & HPV-11 & HPV-16 & HPV-18 \\
\hline
\end{tabular}

\begin{tabular}{lrllll}
\hline CIN grade 2/3 & 5 & 3 & - & 1 & 1 \\
CN grade 2/3+virus & 11 & 3 & 1 & 6 & 2 \\
Virus alone & 4 & 2 & - & 1 & 1 \\
No CIN or virus & 3 & 1 & - & 1 & 1 \\
Squamous cancer & 3 & 2 & - & 1 & - \\
\hline Total & 26 & 11 & 1 & 10 & 5
\end{tabular}

$\mathrm{CIN}=$ cervical intraepithelial neoplasia.

HPV-16 DNA was found to be integrated in four cases (one case of CIN grade 3 with koilocytosis, one of viral koilocytic atypia, one of chronically inflamed cervix, and one of invasive cancer). HPV-18 DNA was found to be integrated in two cases (one case of CIN grade 3 with koilocytosis and one of chronically inflamed cervix). Both HPV-18 and HPV-1 episomal DNA was found in one case of CIN grade 3 plus virus. No HPV-6 DNA was found.

\section{$\underline{\underline{m}}$ ग œ @ํㅡㄹ 标


HPV-18 probe in stringent conditions (fig $3 A, g$ ). These bands proved to be HPV-11 DNA as shown by their hybridisation pattern to the HPV-11 DNA probe in stringent conditions (fig $1 B, a-c$ and fig $3 B, e$ ).

It has been reported that Bam HI cuts HPV-18 DNA twice'; in this series, however, digestion with Bam $\mathrm{HI}$ consistently produced only one band that comigrated with EcoRI linear HPV-18 DNA (fig $3 B, a-c$ ), indicating

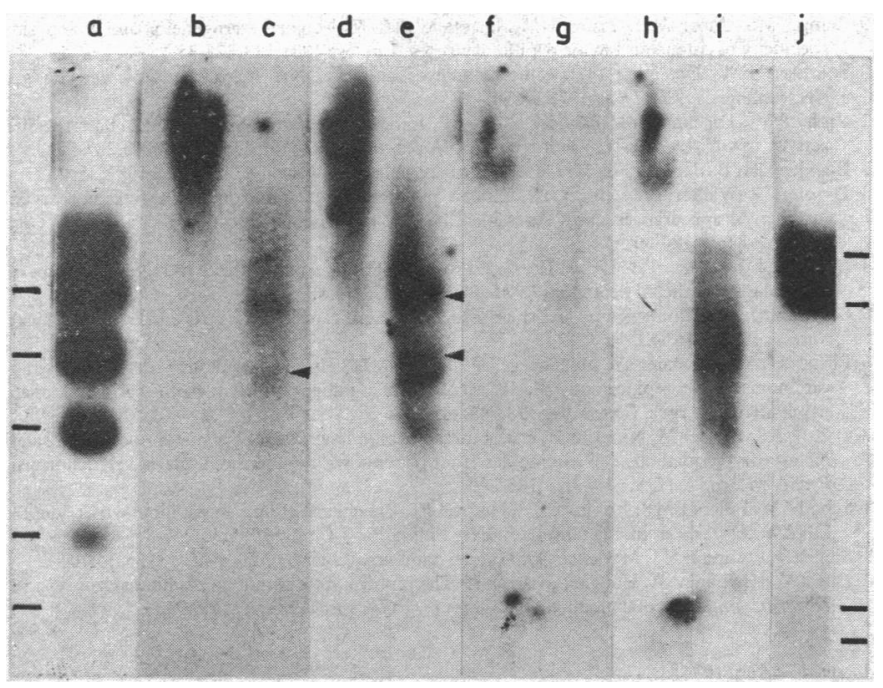

FIG 2-Detection of integrated HPV DNA sequences in cervical biopsy specimens. Tissue DNA hybridised to HPV-16 and HPV-18 probes labelled with phosphorus-32. $a$, recombinant HPV-16 plasmid DNA digested with PstI; $b, c$, cervical intraepithelial neoplasia (CIN) grade 3 with koilocytic atypia; $d, e$ chronically inflamed cervix; $f, g, C I N$ grade 3 with koilocytic atypia; $h, i$ chronically inflamed cervix; and $j$, EcoRI linear HPV-18 DNA digested with PstI. In each case the first track contains non-digested DNA and the second track DNA digested with PstI. The amount of DNA was $10 \mu \mathrm{g}$ in $b, c$ and $5 \mu \mathrm{g}$ in $d-i$. Hybridisation was to labelled HPV-16 DNA $(a-e)$ and to labelled HPV-18 DNA $(f-j)$ as described in fig 1 . Black lines indicate viral DNA fragments. The top band in track $a$ is due to plasmid vector DNA sequences still linked to HPV-16 DNA The arrowheads in $c, e$ indicate bands that probably represent junctions between cellular and viral DNA. The band in $c$ is more clearly seen in the original autoradiograph.

(A)

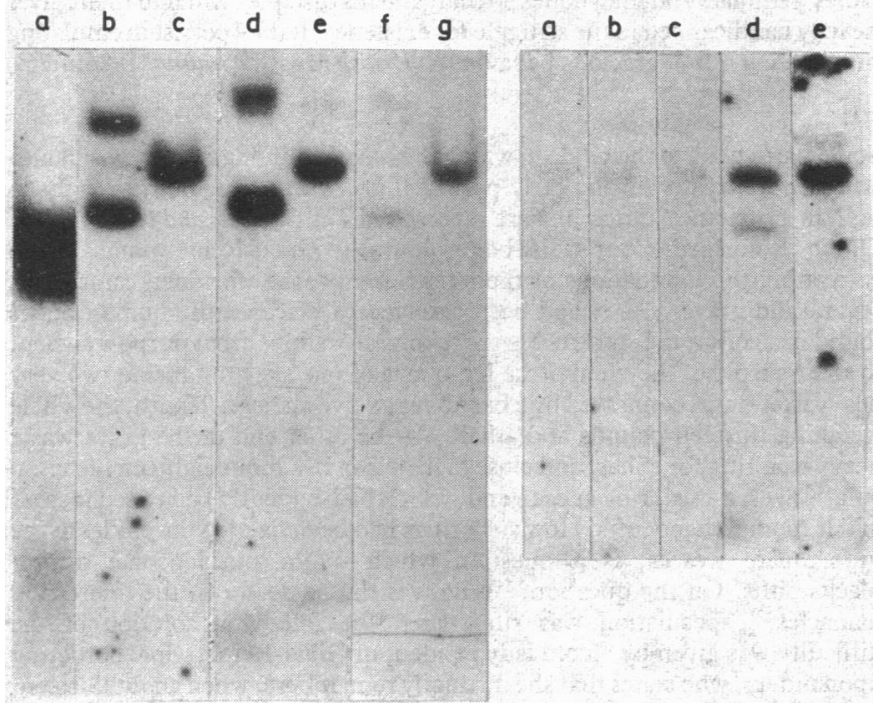

FIG 3-Detection of HPV-18 DNA sequences in cervical biopsy specimens. $A$ : The blot shown in fig $1 A$ was washed in $0.1 \times S S C$ at $75^{\circ} \mathrm{C}$ to remove hybridised HPV probes, rehybridised to HPV-18 DNA labelled with phosphorus-32 in $40 \%$ formamide and $5 \times S S C$ at $42^{\circ} \mathrm{C}$, and washed extensively in $0 \cdot 1 \times S S C$ at $60^{\circ} \mathrm{C} . a-g$, as in fig $1 A$. B: Bam HI digested DNA. $a-c$, same cases as $b, d, f$ in $A ; d$, EcoRI linear HPV-18 DNA; $e$, same as $c$. $a$ - $d$ were hybridised to HPV-18 DNA labelled with phosphorus-32 and $e$ to HPV-11 DNA labelled with phosphorus-32 in $40 \%$ formamide and $5 \times S S C$ at $42^{\circ} \mathrm{C}$ and washed as in $A$. The lower band in $d$ is due to residual plasmid sequences hybridisation. The amount of DNA was $5 \mu \mathrm{g}(a)$, $2 \cdot 5 \mu \mathrm{g}(b)$, and $10 \mu \mathrm{g}(c)$. polymorphism of the recognition site for this enzyme. Polymorphism of the restriction enzyme site, possibly linked to geographical distribution, is a known phenomenon among papillomaviruses. ${ }^{16} 17$

In the remaining two specimens positive for HPV-18 sequences, from cervical intraepithelial neoplasia grade 3 with koilocytosis and a chronically inflamed cervix, the viral DNA seemed to be integrated, as shown by its comigration with cellular DNA in untreated samples (fig $2 f, h$ ). Moreover, the bands in the samples treated with PstI did not correspond to the viral genomic DNA bands (fig $2 g, i$ ), suggesting rearrangements, in agreement with previous reports. ${ }^{7}$ Alternatively, the viral DNA in these two samples may have belonged to other unidentified HPV types related to HPV-18.

\section{Discussion}

The aim of determining the type of HPV in cervical biopsy specimens is to improve the identification and subsequent follow up of those patients who are at increased risk of developing cervical carcinoma.

HPV-16 and HPV-18 DNA sequences were first detected in cervical carcinomas of women from Germany, Brazil, and Africa, ${ }^{67}$ and subsequently the presence of HPV-16 DNA in cervical carcinoma has been reported elsewhere, including in the United Kingdom, ${ }^{18}$ thus confirming the close association of this virus with the malignancy. To date, however, HPV-18 has not been reported in cervical lesions in the United Kingdom. ${ }^{19}$ We found HPV-18 DNA in one third of the samples positive for HPV sequences, or $19 \%$ of the total cases. In addition, although we have not yet detected HPV-18 DNA in frank cancers, other workers in Glasgow have found it in two cases of squamous carcinoma of the cervix and the vulva (J MacNab, personal communication).

The patients in this series were all women living in the west of Scotland, whereas previous surveys dealt primarily with patients living in the south east of England. ${ }^{14} 18$ The difference in the incidence of infection with HPV-16 and HPV-18 may reflect a different geographical distribution of these two viruses, as described by Boshart and colleagues.'

We found HPV-18 DNA in cases of cervical intraepithelial neoplasia grades 2 and 3 and, most remarkably, in a case of koilocytic atypia, indicating viral infection, and also in a case of inflammation of the cervix, in which the viral DNA seemed to be integrated. Neither of the cases of koilocytic atypia and inflammation of the cervix showed histological evidence of cervical intraepithelial neoplasia, although cervical intraepithelial neoplasia might have been present in areas adjacent to the site of the punch biopsy. Given the association of HPV-18 with cancer, the detection of its DNA in lesions that may be an early stage in the events leading to squamous carcinoma may provide a useful marker of subjects at increased risk.

In one case of cervical intraepithelial neoplasia grade 3 with koilocytosis, both HPV-18 and HPV-11 DNA were present. Mixed infections are relatively common ${ }^{6}$ and HPV-11 DNA has been found in cervical cancers, ${ }^{5}$ but the contribution of a mixed infection to malignant progression is at present unknown.

HPV-16 DNA was identified in 10 of the 26 specimens analysed, which contained all five histological categories. It was found in an episomal state in six cases, two of which were antigen positive and presumably producing virus, and was integrated in four cases (an invasive cancer, cervical intraepithelial neoplasia grade 3 with koilocytosis, koilocytic atypia, and a chronically inflamed cervix). Integrated HPV DNA was present in two specimens from chronically inflamed cervixes that showed no histological evidence of cervical intraepithelial neoplasia. HPV-16 DNA sequences have also been detected in inflammatory cervical smears by other workers (J Arrand, personal communication). Chronic inflammation of the cervix, like koilocytic atypia, may be an early stage in the transformation process, and, given the current views of the role of HPV in cervical carcinogenesis, the presence of integrated HPV sequences may indicate an even greater risk of cancer. Indeed, HPV DNA in cancers is usually integrated and integration of the viral sequences seems to accompany malignant progression. ${ }^{20}$ Although the role of integration in malignant conversion remains to be elucidated, the identification of patients at increased risk might be 
refined by looking for integrated rather than episomal viral DNA in early lesions.

These considerations should influence the development of diagnostic procedures to discriminate rapidly between integrated and episomal forms. At present the available techniques, although useful for detecting the presence of viral DNA, are inappropriate for large scale screening of integrated viral genomes because of the resources required.

The possible viral aetiology of cervical lesions points to the desirability of an accompanying screening policy for sexual partners, as a successful treatment of viral cervical lesions would depend on the concomitant treatment of the partner.

We gratefully acknowledge the technical help of Isa Forrest. The HPV-6, 11,16 , and 18 plasmids were a generous gift from Dr L Gissmann. This work was funded by the Cancer Research Campaign, of which MSC is a fellow.

\section{References}

1 Rotkin I. A comparison review of key epidemiological studies in cervical cancer related to current searches for transmissible agents. Cancer Res 1973;33:1353-67.

2 Campion MJ, Singer A, Clarkson PK, McCance DJ. Increased risk of cervical neoplasia in consorts of men with penile condylomata acuminata. Lancet 1985; ; :943-5.

3 Zur Hausen $H$. Human genital cancer: synergism between two virus infections or synergism between a virus infection and initiating events? Lancet 1982;ii:1370.

4 Smith KT, Campo MS. The biology of papillomaviruses and their role in oncogenesis. Anticancer Research 1985;5:31-48.
5 Gissman L, Wolnik L, Ikenberg H, et al. Human papillomavirus types 6 and 11 DNA sequences in genital and laryngeal papillomas and in some cervical cancers. Proc Natl Acad Sci USA 1983;80:560-3.

6 Durst M, Gissmann L, Ikenberg H, Zur Hausen H. A papillomavirus DNA from a cervical carcinoma and its prevalence in cancer biopsies from different geographic regions. Proc Nat Acad Sci USA 1983;60:3812-5.

7 Boshart M, Gissmann L, Ikenberg H, et al. A new type of papillomavirus DNA, its presence in genital cancer biopsies and in cell lines derived from cervical cancer. EMBO f 1984:3:1151-7. Chirgwin JM, Przybyla AE, Macdonald RJ, Rutter WF. Isolation of biologically active ribonucleic acid from sources enriched in ribonuclease. Biochemistry 1979;18:5294-9.

9 Campo MS, Moar MH, Laird HM, Jarrett WFH. Molecular heterogeneity and lesion site specificity of cutaneous bovine papillomaviruses. Virology 1981;113:323-35.

10 Southern EM. Detection of specific sequences among DNA fragments separated by gel electrophoresis. F Mol Biol 1975;98:503-17.

11 Rigby PWJ, Dieckmann $M$, Rhodes $C$, Berg P. Labelling deoxyribonucleic acid to high specific activity in vitro by nick-translation with DNA polymerase I. $\mathcal{F ~ M o l ~ B i o l ~ 1 9 7 7 ; 1 1 3 : 2 3 7 - 5 1 . ~}$

12 Buckley CH, Butler EB, Fox H. Cervical intraepithelial neoplasia. 7 Clin Pathol 1982;35:1-13.

13 Dyson JL, Walker PG, Singer A. Human papillomavirus infection of the uterine cervix: histological appearances in 28 cases identified by immunohistochemical techniques. $\mathcal{J}$ Clin Pathol 1984;37:126-30.

14 McCance DJ, Walker PA, Dyson JL, et al. Presence of human papillomavirus DNA sequences in cervical intraepithelial neoplasia. BrMed f 1983;287:784-8.

15 Gissmann L. Papillomaviruses and their association with cancer in animals and in man. Cancer Surveys 1984;3:161-81.

16 Pfister H, Gossenmaier A, Nurnberger F, Stuttgen G. Human papillomavirus-5 DNA in a carcinoma of an epidermodysplasia verruciformis patient infected with various human papillomavirus types. Cancer Res 1983;43:1436-41.

17 Ostrow RS, Bender M, Niimura $M$, et al. Human papillomavirus DNA in cutaneous primary and metastasized squamous cell carcinomas from patients with epidermodysplasia verruciformis. Proc Natl Acad Sci USA 1982;79:1634-8.

18 Scholl SM, Pillers EMP, Robinson RE, Farrell PJ. Prevalence of human papillomavirus type 16 DNA in cervical carcinoma samples in East Anglia. Int f Cancer 1985;35:215-8.

19 Singer A, Campion MJ, McCance DJ. Human papillomavirus. Br f Hosp Med 1985;34:104-8.

20 Durst M, Kleinheinz A, Hotz M, Gissman L. The physical state of human papillomavirus type 16 DNA in benign and malignant genital tumours. $\mathcal{F}$ Gen Virol 1985;66:1515-22.

(Accepted 30 April 1986)

100 YEARS AGO

The Belgian police were reported, a day or two since, to have made a "ghastly discovery," which appeared to warrant the supposition that a crime had been committed on the lines laid down by Wainwright, in England, and improved upon by Billoir, in France. Since, however, it is stated to be only a "ghastly joke" by medical students. If that be the true version of the affair, it is sincerely to be hoped that a salutary lesson will be meted out to those frolicsome youths who trifle thus with other people's feelings. It is, however, to be feared that the verdict of "the medical student again," is sometimes arrived at with too much alacrity, and, in the absence of that absolute certainty which alone should determine an explanation involving the cessation of further inquiry. A positive injustice, involving a whole class, is not unfrequently committed by the publication of the designation "medical student," as applied to any rowdy nondescript who figures in the policecourt, and who is not called upon to furnish any proof of his connection with a medical school. In years gone by, rowdyism was condoned by magistrates, when the offender could plead either that he was intoxicated or that he was a medical student. We are pleased to note that, at present, a change has come o'er the spirit of the dream. Drunkenness has come to be considered an aggravation of disorderly conduct, rather than a palliative, and to plead the professional nature of one's studies as an excuse for misconduct, is about as great a blunder as could be committed-for the magistrate is now inclined to consider that misconduct is all the more reprehensible on the part of people who ought to know better. There are, it is true, occasional instances of organised outbreaks on the part of students: such, for example, as the annual scene at the Criterion, on the evening of Lord Mayor's Day; but the more conspicuous of the rioters are generally secured, and sharply dealt with by the district magistrate, and the heavy pecuniary penalties of late years have tended to discourage that form of amusement. Hospital authorities, too, have very properly taken the matter in hand, and the conviction of a student for drunkenness and disorderly conduct, inevitably adds to his rustication or even expulsion, the latter being equal to a fine of over $£ 100$, since no fees are returned, not to speak of the disrepute which such expulsion must involve for the delinquent. The general tone of the mass of students is yearly improving; the rising generation of students are too much preoccupied by the constantly-increasing requirements of the examining boards, to have more spare energy left than can easily be disposed of at football or cricket. The great wave of temperance, too, may be credited with a large share in the reform. Habits of alcoholic abuse are, no doubt, still lamentably common among the students of our London schools; but they are far less than in years gone by. There is every reason to hope that the civilizing influences which have wrought so wonderful a change in the habits and customs of society in this matter, will ultimately extend to the would-be Bohemian student. Bohemianism is at a discount now-a-days, and, assuredly, now that artists and poets can dress like other peor,je, and talk like other people, we can dispense with the man-savage, labell sd though he be as a "medical." We are no advocate for a sedateness of demeanour that would better befit a young ladies' seminary, but Sawbones is dead, and his disciples will find themselves heavily handicapped in the stru ggle for existence, if they persist in emulating his amusing but ungracious behaviour. (British Medical fournal 1886;ii:76.)

Some particulars of the inode in which the lunatics among the Boers of South Africa were treated in the early part of this century have been brought to light in a curious manner, and are reported in The Colonies and India. A new Dutch Reformed Church is being built in Graaf-Reinet; and, while excavating the foundations of the west transept, the workmen came upon several old graves. As it had been resolved to place all the human bones found in a coffin, the workmen were taking them up for that purpose, when, to their surprise, they found the leg-bones of one skeleton inside two very heavy iron rings, connected by a bar about twelve inches in length, the whole weighing thirteen pounds and a half. At the other end of the grave was a heavy iron ring, or collar, and close to it an iron bar about eighteen inches in length, with a small ring at each end, which had evidently been used instead of our modern handcuffs. How such rings had been fixed to the ankles of the unfortunate wearer, is a question which might puzzle some of our blacksmiths. On the question, "Who was the possessor of the interesting manacles?" speculation was rife, when the following solution of the difficulty was given by an old lady resident of Graaf-Reinet, now bordering upon ninety, who states that she distinctly remembers, when about thirteen, coming into town from the Sneeuwberg, and seeing a maniac, named Koekemoer, heavily manacled, allowed to go about the streets; a perfect terror to little girls, who would hardly venture outside the door for fear of meeting him. Sometimes he was knee-haltered by a chain fixed to an iron collar about the neck, to prevent his getting into mischief. At other times, he might go erect, having only chains on hands and feet. If the question should be raised as to the improbability of burying such an object of pity with chains and all, it might be answered that a Government or a public that could thus treat him during life would find little scruple in saving themselves the trouble of removing, after death, such heavy iron rings as have been dug out of the old graves. (British Medical fournal 1886;i:895.) 